\title{
Circadian rhythms in peak expiratory flow rate in workers exposed to cotton dust
}

\author{
FF CINKOTAI, TC SHARPE, ACC GIBBS \\ From the Department of Occupational Health, University of Manchester
}

ABSTRACT One hundred and sixty two people working in various departments of cotton spinning and weaving mills measured and recorded their own peak expiratory flow rate (PEFR) at two hourly intervals during Monday, Wednesday, and Thursday of the same work week, from waking in the morning throughout the day until going to bed and a last time the following morning after waking. The circadian rhythm in PEFR was computed by the Halberg program. The mean amplitude of the rhythm in the group was found to be $3.3 \%$ and the acrophase fell approximately in the middle of the waking hours. Older workers and those claiming to suffer from symptoms of chronic bronchitis were found to have an amplitude significantly higher $(4 \cdot 1 \%$ and $3.9 \%$ respectively) than their younger or symptom free counterparts $(2.6 \%$ and $2.9 \%$ respectively; $p<0.03)$. The amplitude of cardroom workers $(2 \cdot 4 \%)$, workers with byssinosis $(2 \cdot 7 \%)$, and those with much exposure to airborne cotton dust $(3.3 \%)$ and bacteria $(2.9 \%)$ tended to be lower than that of less exposed groups such as office staff (3.9\%), though the difference was significant only in the case of cardroom workers $(p<0.04)$. This may be due to airborne contaminants in the working environment.

Of the many indices available for monitoring ventilatory function in man, the peak expiratory flow rate (PEFR) is probably the only index which can be measured simply and reliably. People can be easily taught to use a small, portable, inexpensive peak flow meter to measure their own PEFR. The index is thus justly popular for monitoring the ventilatory function of asthma sufferers in the home.

Hetzel and Clark' have shown that ventilatory function as monitored by the PEFR changes "rhythmically" during the day in normal, healthy adults as well as in people suffering from asthma. From measurements of PEFR made four times daily for seven consecutive days they found the acrophase of this circadian rhythm to be at the midpoint of waking hours and the bathyphase to be during sleep in both groups. The amplitude of the change was $8 \%$ of the mesor (average value during the day) for normal people, whereas it was up to $25 \%$ for asthma sufferers. Similar results have been reported by others. ${ }^{2-5}$

Ventilatory function may be acutely affected by occupational exposure to dust, especially to that of

Address for reprint requests: Dr FF Cinkotai, Department of Occupational Health, Stopford Building, Manchester M13 9PT.

Accepted 9 May 1984 vegetable or organic origin. Indices of expiratory capacity such as indirect maximum breathing capacity (IMBC), forced expiratory volume (FEV), forced vital capacity (FVC), and airway conductance have been found to decline considerably during the work shift, especially in workers with byssinosis exposed to airborne cotton dust in cotton spinning mills. ${ }^{6-8}$ Similar though less conspicuous effects have also been observed in workers exposed to airborne dust in flax, ${ }^{10}$ hemp, ${ }^{11} 12$ jute,,$^{73}$ and wool mills ${ }^{14}$ and in tobacco factories, ${ }^{15}$ tea packing plants, furniture factories, ${ }^{16}$ and coal mines. ${ }^{17} 18$ In many cases the effects of dust exposure have been found to override the normal circadian rhythm in FEV and FVC that can be discerned from past surveys of lung function in other industrial workers. ${ }^{619-21}$ The information available on the circadian rhythm in PEFR in workers exposed to dust is inconclusive. ${ }^{6}$

It has been suggested that histamine is released in the bronchi of those with byssinosis when they are exposed to cotton dust and that this causes bronchial constriction, which is reflected by an acute fall in ventilatory capacity. As this mechanism is not unlike that believed to operate when asthma sufferers are exposed to their allergen, byssinosis has been suggested to be possibly a form of occupational asthma. The present project was undertaken partly to test 
this hypothesis and partly to study the circadian rhythm in PEFR in an industrial population exposed to a dust known to affect the ventilatory system.

\section{Methods}

\section{STUDY POPULATION}

In all, 162 people-78 men and 84 women-took part in the study: 57 worked in a mill spinning very low grade cotton (Mill L), 49 in a mill spinning medium grade cotton (Mill $\mathbf{M}$ ), 28 in a shed weaving sized cotton (Mill W), and 28 in offices near the weaving shed (table 1). Of these, 69 were smokers, 19 ex-smokers, and 74 non-smokers; 98 had been in their present job for longer than five years and 36 were newcomers who had worked at their job for less than a year. Of the people employed in spinning mills, 24 worked in a blowroom or cardroom, 29 in a ringroom, and 53 in a winding or doubling or beaming room. Cotton workers worked two alternating shifts: morning ( 6 am to $2 \mathrm{pm}$ ) and afternoon shifts $(2 \mathrm{pm}$ to $10 \mathrm{pm})$. Office staff worked from 8 am to $4.30 \mathrm{pm}$.

All participants were unselected volunteers. All but a few people working in a particular shift in the workrooms listed in table 1 were asked to participate and all agreed except three workers in the cardroom of Mill $\mathrm{M}$ and two in the cardroom and four in the winding room of Mill L. Some refused because they did not wish to carry the dust samplers and others because they were not prepared to perform lung fuction tests. Three people in the ringroom and two in the winding room of Mill $M$ were excluded from the study because they were illiterate, as were two people in the ringroom and two in the winding room of Mill L. A further three persons were excluded from the study because they did not return satisfactory records.

\section{MEASUREMENTS}

In a preliminary session a Medical Research Council respiratory questionnaire supplemented with questions about symptoms of byssinosis and occupational history was completed for each volunteer, who then was carefully taught to use a mini Wright peak flow meter and the Vitalograph.

Ventilatory indices were then monitored in each person on Mondays, Wednesdays, and Thursdays of a week when spinners and weavers worked a $6 \mathrm{am}-2 \mathrm{pm}$ morning shift. People were asked to measure their own PEFR in triplicate at two hourly intervals and record them throughout the waking hours from the beginning of the Monday workshift to the beginning of the Tuesday shift and from the beginning of the Wednesday shift to the beginning of the Friday shift. Each person was provided with a mini Wright peak flow meter to use in the factory and at home, a recording sheet, and a timer pinned to the lapel to indicate the lapse of a two hour period. All except a few participants recorded 10 triplicate PEFR measurements for each study day and the time of day to the nearest minute when the test was performed. A few people were prevented from participating on a Thursday by some unforeseen event such as illness. In such cases measurements made on a subsequent Thursday were substituted. All records were stored anonymously in a computer databank.

Table 1 Workplace, number, and personal characteristics of participants

\begin{tabular}{|c|c|c|c|c|c|c|c|c|c|c|c|c|}
\hline \multirow[t]{2}{*}{ Factory } & \multirow[t]{2}{*}{ Workshop } & \multirow{2}{*}{$\begin{array}{l}\text { No of } \\
\text { participants }\end{array}$} & \multirow{2}{*}{$\begin{array}{l}\text { Age: } \\
\text { median, } \\
\text { range }\end{array}$} & \multirow{2}{*}{$\begin{array}{l}\text { Years } \\
\text { worked in } \\
\text { mill: mean, } \\
\text { range }\end{array}$} & \multicolumn{8}{|c|}{ Number of } \\
\hline & & & & & men & wor & n smokers & $\begin{array}{l}\text { ex- } \\
\text { smokers }\end{array}$ & $\begin{array}{l}\text { non- } \\
\text { smokers }\end{array}$ & $\begin{array}{l}\text { symptom } \\
\text { free }\end{array}$ & $\begin{array}{l}\text { with } \\
\text { symptoms } \\
\text { but not } \\
\text { byssinosis }\end{array}$ & $\begin{array}{l}\text { with } \\
\text { byssinos }\end{array}$ \\
\hline \multirow{4}{*}{$\begin{array}{l}\text { Mill L } \\
\text { (spinning low } \\
\text { grade cotton) }\end{array}$} & $\begin{array}{c}\text { Cardroom, } \\
\text { blowroom }\end{array}$ & 10 & \multirow{9}{*}{$\begin{array}{l}45 \cdot 0 \\
19-55 \\
43 \cdot 0 \\
19-57 \\
48 \cdot 5 \\
18-60 \\
46 \cdot 0 \\
19-62 \\
31 \cdot 5 \\
17-42 \\
27 \cdot 8 \\
17-55 \\
44 \cdot 5 \\
18-57 \\
28 \cdot 4 \\
17-63 \\
30 \cdot 5 \\
27-63\end{array}$} & \multirow{4}{*}{$\begin{array}{l}16 \cdot 8 \\
0 \cdot 5-42 \\
22 \cdot 4 \\
4-44 \\
21 \cdot 1 \\
1-39 \\
19 \cdot 6 \\
1-40\end{array}$} & 10 & 0 & 8 & 0 & 2 & 3 & 4 & 3 \\
\hline & Ringroom & 12 & & & 4 & 8 & 8 & 1 & 3 & 5 & 5 & 2 \\
\hline & Winding room & 15 & & & 5 & 11 & 5 & 0 & 11 & 6 & 5 & 4 \\
\hline & $\begin{array}{l}\text { Doubling/ } \\
\text { beaming room }\end{array}$ & 20 & & & 4 & 15 & 4 & 1 & 14 & 6 & 9 & 5 \\
\hline \multirow{3}{*}{$\begin{array}{l}\text { Mill M } \\
\text { (spinning } \\
\text { medium grade } \\
\text { cotton) }\end{array}$} & $\begin{array}{l}\text { Cardroom, } \\
\text { blowroom }\end{array}$ & 14 & & \multirow{3}{*}{$\begin{array}{l}16 \cdot 1 \\
1-40 \\
10 \cdot 2 \\
0 \cdot 4-24 \\
22 \cdot 7 \\
3-44\end{array}$} & 9 & 5 & 5 & 3 & 6 & 6 & 6 & 2 \\
\hline & Ringroom & 17 & & & 17 & 0 & 10 & 1 & 6 & 10 & 7 & 0 \\
\hline & Winding room & 18 & & & 3 & 15 & 9 & 1 & 8 & 4 & 13 & 1 \\
\hline \multirow{2}{*}{$\begin{array}{l}\text { Mill W } \\
\text { (weaving sized } \\
\text { cotton) }\end{array}$} & Weaving shed & 28 & & \multirow{2}{*}{$\begin{array}{c}8 \cdot 0 \\
1-32\end{array}$} & 20 & 8 & 13 & 8 & 7 & 15 & 13 & 0 \\
\hline & Office & 28 & & & 6 & 22 & 7 & 4 & 17 & 16 & 12 & 0 \\
\hline Total & & 162 & & & 78 & 84 & 69 & 19 & 74 & 71 & 74 & 17 \\
\hline
\end{tabular}


The FEV 1 and FVC were measured in triplicate before and after the work shift on each study day with a dry spirometer (Vitalograph). Both of these volumes were corrected to BTPS from the ambient temperature and pressure, read at the time of the measurement. The forced expiratory flow rates (FEF) after exhalation of $25 \%$ of FVC $\left(\mathrm{FEF}_{75}\right)$ and $75 \%$ of FVC $\left(\mathrm{FEF}_{25}\right)$ were estimated from the best curve on the Vitalograph.

The concentration of airborne dust less " $f l y$ " in the breathing zone was determined for each participant during his or her entire shift on all three study days with the Casella personal dust sampler. The sampling head, covered by a small wire gauze to exclude "fly," was attached to a harness (worn by each participant) near the clavical region and the pump was attached to the waist belt. The sampling rate was set to $.21 \mathrm{~min}^{-1}$ and frequently checked. The concentration of airborne dust in the general environment of the workshop where the participants worked was concurrently monitored with Rotheroe-Mitchell L60 dust samplers. Five or six such instruments were set up at a height of $1.5 \mathrm{~m}$ in the workshop at selected positions that covered the work zone evenly. The dust sample was drawn through a wire gauze cage of $23 \times 27 \times 37 \mathrm{~cm}$ and $2 \mathrm{~mm}$ mesh to exclude "fly" at a rate of around 551 $\min ^{-1}$, which was variable and had to be frequently checked. The samples were collected on glass fibre filters (GF/A), which were conditioned and weighed on a Cahn electromicrobalance before and after the sampling. The concentration of airborne viable bacteria was derived from two samples of 2 minutes' duration collected during each study shift at the same sampling positions as those for the environmental dust, the Anderson viable sampler (a six stage, multiple jet cascade impactor) being used. The bacteria were impacted on plates of nutrient agar medium, which were then incubated for 24 hours at $36^{\circ} \mathrm{C}$ and for a second 24 hours at room temperature, before the number of colony forming units (CFU) was counted and the $\mathrm{CFU} / \mathrm{m}^{3}$ air was calculated from the rate and duration of sampling.

\section{Results and statistical analysis}

\section{RESPIRATORY SYMPTOMS QUESTIONNAIRE}

The questionnaires show (table 1) that 64 participants claimed to suffer from symptoms of chronic bronchitis but not byssinosis (bouts of phlegm production during recent years for periods longer than three months at a time) and 17 cotton workers from symptoms of byssinosis (chest tightness or breathlessness, or both, during the first shift of the working week not attributable to any obvious cause). Most of the latter workers claimed to suffer also from symp- toms of chronic bronchitis; all of them were employed in jobs they had held throughout their career in the cotton industry and they were all receiving a byssinosis pension (that is, they had been found to suffer from byssinosis by a pneumoconiosis panel). One byssinotic worker who had worked in a cardroom for 23 years claimed to suffer from clear symptoms of nocturnal asthma and displayed a circadian rhythm in PEFR with a highly consistent but exaggerated amplitude $(25 \%)$ that differed from all others. For this reason he was excluded from the study after the initial stages of statistical analysis.

EXPOSURE TO AIRBORNE DUST AND BACTERIA All workers, except office staff, were exposed to airborne cotton dust. Concentrations measured in the breathing zone ranged on average from 0.59 to $4.63 \mathrm{mg} / \mathrm{m}^{3}$ (table 2). As expected, dust concentrations were highest in the mill where low grade cotton was spun and lowest in the weaving shed. Cardrooms were considerably dustier than subsequent workrooms and concentrations in the general environment were significantly less than those measured in workers' breathing zones by personal sampling. Concentrations of bacteria in the general environment varied from 1600 to $150000 \mathrm{CFU} / \mathrm{m}^{3}$.

\section{CHANGES IN FEV, FVC, AND FEF DURING} WORKSHIFT

As observed before by others, the forced expiratory volume $\left(\mathrm{FEV}_{1}\right)$ tended to fall slightly during the work shift in cotton spinners and to remain unchanged or rise slightly in weavers and office workers. Changes in volumes were smaller than those previously observed and were significant in only a few cases (table 2). Changes in forced expiratory flow showed no particular pattern, most probably because of the very high variability in these indices, especially in $\mathrm{FEF}_{25}$ (table 2). A small but significant increase in $\mathrm{FEF}_{75}$ during work shift could, however, be discerned in weavers and office workers.

\section{CIRCADIAN RHYTHM IN PEFR}

To analyse the circadian rhythm in PEFR, the maximum value (PEFR') was selected from each set of two hourly triplicate readings (the other two were discarded) and normalised to a percentage (P\%) of the average PEFR' for the day $(\mathrm{P} \%=100 \times$ $\mathrm{PEFR}^{\prime} /$ mean PEFR'). When the mean P\% values for all subjects and study days were plotted against the time of day a distinct circadian rhythm emerged (fig). Scattergrams for individuals, however, varied considerably, some showing no apparent rhythm, others a very noticeable one.

To display the underlying rhythm we attempted to 
Table 2 Participants' exposure to airborne dust and bacteria and changes in their ventilatory capacity from the beginning to the end o $\overline{\bar{B}}$ their workshifts

\begin{tabular}{|c|c|c|c|c|c|c|c|c|}
\hline \multirow[t]{2}{*}{ Factory } & \multirow[t]{2}{*}{ Workshop } & \multicolumn{2}{|c|}{ Mean (SD) dust concentration } & \multirow{2}{*}{$\begin{array}{l}\text { Mean }(S D) \\
\text { bacteria } \\
\text { concentration in } \\
\text { workshop air } \\
\left(C F U \times 10^{4}\right)\end{array}$} & \multicolumn{4}{|c|}{ Mean (SE) change during workshift } \\
\hline & & $\begin{array}{l}\text { Breathing } \\
\text { zone }\left(m g / m^{3}\right)\end{array}$ & $\begin{array}{l}\text { Workshop air } \\
\left(m g / m^{3}\right)\end{array}$ & & $F E V(l)$ & $F V C(l)$ & $\begin{array}{l}F E F_{15} \\
\left(l \min ^{-1}\right)\end{array}$ & $\begin{array}{l}F E F_{25} \\
\left(l_{\text {min }^{-}}\right.\end{array}$ \\
\hline \multirow{6}{*}{$\begin{array}{l}\text { Mill L } \\
\text { (spinning low } \\
\text { grade cotton) }\end{array}$} & $\begin{array}{l}\text { Cardroom, } \\
\text { blowroom }\end{array}$ & $4 \cdot 63(3 \cdot 18)$ & $1 \cdot 34(0 \cdot 18)$ & $15 \cdot 0(11 \cdot 2)$ & \multirow{6}{*}{$\begin{array}{l}-0.080 \\
(0.048) \\
-0.051 \\
(0.025)^{*} \\
-0.034 \\
(0.019) \\
-0.031 \\
(0.23)\end{array}$} & \multirow{6}{*}{$\begin{array}{l}-0.066 \\
(0.050) \\
-0.041 \\
(0.037) \\
-0.105 \\
0.021)^{* * *} \\
-0.052 \\
(0.019)^{* *}\end{array}$} & \multirow{6}{*}{$\begin{array}{l}0.77 \\
0.70) \\
-0.37 \\
(0.32) \\
-0.60 \\
(0.22)^{* *} \\
0 \cdot 10 \\
(0.17)\end{array}$} & \multirow{6}{*}{$\begin{array}{l}0.074 \\
0.062) \\
-0.009 \\
0.074) \\
-0.001 \\
(0.43) \\
-0.033 \\
(0.43)\end{array}$} \\
\hline & Ringroom & $1 \cdot 59(1.08)$ & $1 \cdot 36(0 \cdot 10)$ & $4 \cdot 5(1 \cdot 1)$ & & & & \\
\hline & & & & & & & & \\
\hline & Winding room & $2 \cdot 73(1.88)$ & $2 \cdot 28(0 \cdot 49)$ & $8 \cdot 18(0 \cdot 56)$ & & & & \\
\hline & Doubling/ & $1 \cdot 27(0 \cdot 67)$ & $0.96(0.26)$ & $6.39(3.42)$ & & & & \\
\hline & beaming room & & & & & & & \\
\hline \multirow{4}{*}{$\begin{array}{l}\text { Mill M } \\
\text { (spinning } \\
\text { medium grade } \\
\text { cotton) }\end{array}$} & Cardroom, & $1 \cdot 71(1 \cdot 53)$ & $1 \cdot 27(0 \cdot 11)$ & $1 \cdot 81(0 \cdot 77)$ & \multirow{4}{*}{$\begin{array}{l}-0.042 \\
(0.16) \\
-0.002 \\
(0.019) \\
-0.007 \\
(0.014)\end{array}$} & \multirow{4}{*}{$\begin{array}{l}-0.055 \\
(0.015)^{* * *} \\
-0.029 \\
(0.019) \\
-0.02 \\
(0.018)\end{array}$} & \multirow{4}{*}{$\begin{array}{l}-0.98 \\
(1.58) \\
0.39 \\
(0.30) \\
0.28 \\
(0.12)^{*}\end{array}$} & \multirow{4}{*}{$\begin{array}{l}0.013 \\
(0 \cdot 076) \\
0 \cdot 10 \\
(0.07) \\
0 \cdot 068 \\
(0.053)\end{array}$} \\
\hline & blowroom & $0.59(0.23)$ & $0.53(0.17)$ & $0.15(0.07)$ & & & & \\
\hline & Ning & $9(0.25)$ & (0.17) & $0.12(0.07)$ & & & & \\
\hline & Winding room & $0 \cdot 83(0 \cdot 77)$ & $0.37(0 \cdot 04)$ & $0 \cdot 31(0 \cdot 11)$ & & & & \\
\hline \multirow{3}{*}{$\begin{array}{l}\text { Mill W } \\
\text { (weaving } \\
\text { sized cotton) }\end{array}$} & Weaving shed & \multirow{3}{*}{$1.39(1 \cdot 24)$} & $0.64(0.20)$ & $0 \cdot 16(0 \cdot 06)$ & 0.063 & 0.004 & $\begin{array}{l}(0.12) \\
0.40\end{array}$ & $\begin{array}{l}(0.053) \\
0.14\end{array}$ \\
\hline & & & & & $(0 \cdot 019)^{* * *}$ & $(0.026)$ & $(0 \cdot 14)^{* *}$ & $(0 \cdot 06)^{*}$ \\
\hline & Offices & & $<0.1$ & $<0.01$ & $\begin{array}{l}0.003 \\
(0.018)\end{array}$ & $\begin{array}{l}-0.005 \\
(0.017)\end{array}$ & $\begin{array}{l}0.40 \\
(0.14)^{* *}\end{array}$ & $\begin{array}{l}-0.001 \\
(0.40)\end{array}$ \\
\hline
\end{tabular}

${ }^{*} \mathrm{p}<0.05 ;{ }^{* *} \mathrm{p}<0.01 ;{ }^{* * *} \mathrm{p}<0.001$.

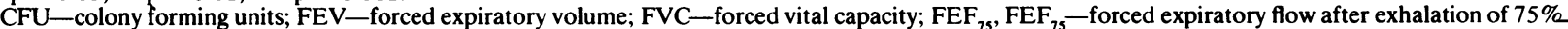
and $25 \%$ of the FVC.

fit to points on a scattergram embracing all subjects and study days a polynomial of degree $\mathbf{n}$ :

$$
\mathrm{P} \%=a_{0}+a_{1} t+a_{2} t^{2}+\ldots+a_{i} t^{i}+\ldots+a_{n} t^{n},
$$

or the cosine function

$$
\mathrm{P} \%=\mathrm{M}+\frac{\mathrm{A}}{2} \cos (\mathrm{w}+\theta),
$$

where $t$ is the time of day, $a_{\mathrm{i}}$ the polynomial coefficients, $M$ the mesor, A the amplitude (distance from peak to trough), w the frequency $(2 \pi / 24)$, and $\theta$ the phase. Cosine waves were fitted by a computer program based on Halberg's cosinor analysis. ${ }^{22}{ }^{23}$ Polynomials were computed degree by degree (with an SSP package ${ }^{24}$ ) and above an $n$ value of 3 no further improvement in fit was obtained except in a few cases. Thus we chose to use cubic polynomials. The mean cubic and cosine curves for the entire group of participants are shown in the figure.

Neither curve follows the asymmetry of the data particularly closely but the polynomial which registers a slightly higher peak 30 minutes earlier appears to fit somewhat better. (This was to be expected since it contained an extra term.) The difference was, however, not overwhelming and therefore we opted for the cosinor analysis, which has in the past been used in most circadian studies.

Next we computed three cosine curves displaying separately the rhythm on Monday, Wednesday, and Thursday for the entire group (table 3). As these curves did not differ significantly, in subsequent analysis a cosine function based on all three study days was found for each individual and indi- vidual curves were combined in the Halberg program (by averaging the coefficients of individual curves) to yield the mean PEFR rhythm in the entire group of volunteers and in subgroups selected according to various personal and occupational criteria (table 3). The mean amplitude of the PEFR

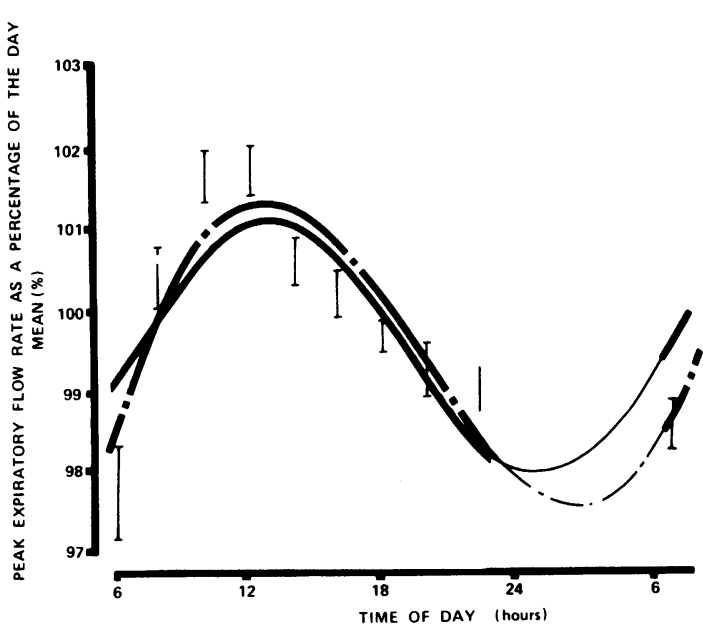

The means and standard errors of the peak expiratory flow rate (as a percentage of the day mean), measured at two hourly intervals throughout three study days in 162 people working in various departments of a cotton weaving and two cotton spinning mills, and the cubic polynomial (- - and cosine $(-)$ curves that best futed the data. 
rhythm in this industrial population was $3.3 \%$ and the acrophase fell to the middle of the waking hours. The mean amplitude in subgroups, selected according to sex, age, smoking habit, years spent in the mill, workshop, work trade, dust or bacteria exposure, changes in FEV or FVC during workshifts and whether the workers claimed bronchitic or byssinotic symptoms, ranged from $2.4 \%$ to $4.3 \%$ (table 3 ).

Cotton workers who participated in the study in a week when they worked from 6 am to $2 \mathrm{pm}$ were found to have a circadian rhythm in PEFR with an amplitude of $3.4 \%$ and an acrophase at 12.56 hours. In contrast, office staff, who worked from $8.00 \mathrm{am}$ to $4.30 \mathrm{pm}$, had an amplitude of $3.9 \%$ and an acrophase at $2.44 \mathrm{pm}$. The difference between the two acrophases was clearly due to going to bed and waking at different times of the day. These and all other group rhythms quoted in table 3 were highly significant $(\mathrm{p}<0.001)$. Individually, however, the PEFR rhythm was significant at a $5 \%$ level in only 69 out of 161 subjects. When people with significant rhythms were grouped together, their mean circadian rhythm showed an amplitude of $5.5 \%$ (table 3 ), which is not dissimilar to the $8.3 \%$ reported by Hetzel and Clark' in a similarly "rhythmic" group of recruits from a variable population. There was still a significant mean rhythm in the remaining group of apparently "non-rhythmic" volunteers but with an amplitude of only $1.9 \%$.

FACTORS ASSOCIATED WITH THE PEFR RHYTHM To explore the factors associated with the PEFR rhythm, a stepwise, multiple linear regression analysis was carried out with an SPSS program package. ${ }^{25}$ Age, sex, smoking habit, workroom, level of exposure to airborne cotton dust or bacteria, years of exposure, and presence of bronchitic or byssinotic symptoms were the independent variables used to predict the PEFR amplitude. (Some variables had a value of 0 or 1 , indicating the presence or absence of certain attributes such as respiratory symptoms or place of work.) The variable that correlated best with amplitude was selected first in the program; then this was combined in turn with progressively less strongly correlating variables until all variables had been included. The presence of bronchitic symptoms was the variable selected first in the program and its regression with amplitude was significant $\left(F_{1,131}=5 \cdot 89, p=0.017\right)$. Age was the next variable selected and it too related significantly to amplitude $\left(\mathrm{F}_{1,130}=4.78, \mathrm{p}=0.031\right)$ without appreciably affecting the earlier relationship $\left(F_{1,130}\right.$ $=5.32, p=0.023$ ). Cardroom (one of the workrooms) was the last variable selected that still related significantly (albeit inversely) to amplitude $\left(\mathrm{F}_{1,129}=4.62, \mathrm{p}=0.033\right)$ without diminishing the significance of the previous two regressions $\left(F_{1,129}=\right.$ $5 \cdot 50, p=0.021$ for bronchitic symptoms and $F_{1,129}$ $=4.98, p=0.027$ for age). Weaving shed, the next variable brought in, did not relate significantly to amplitude $\left(F_{1,128}=2 \cdot 54, p=0 \cdot 11\right)$, neither did any further variables, inclusion of which caused the residual mean square to increase rather than decrease.

Thus an increase in PEFR amplitude is significantly associated with age $(p<0.03)$ and symptoms of chronic bronchitis $(p<0.03)$ and a decrease in amplitude with employment in a cardroom $(p<0.04)$. There is no evidence that any other variable would have correlated with amplitude but is excluded from the regression because of its relationship with variables already selected. Accord-

Table 3 Amplitude and acrophase (time of day) of the circadian rhythm in peak expiratory flow rate in groups of participants selected according to various criteria ( $p<0.001$ for all rhythms)

\begin{tabular}{|c|c|c|c|}
\hline Group & No of participants & $\begin{array}{l}\text { Amplitude as \% of day mean } \\
\text { (95\% confidence limits) }\end{array}$ & $\begin{array}{l}\text { Acrophase ( } h, \text { min) } \\
\text { (95\% confidence limits) }\end{array}$ \\
\hline $\begin{array}{l}\text { All, Monday only } \\
\text { All, Wednesday only } \\
\text { All, Thursday only } \\
\text { All (except asthmatic) } \\
\text { With individually significant }(p<0 \cdot 05) \text { rhythms } \\
\text { Without individually significant rhythms } \\
\text { Cotton workers } \\
\text { Office workers } \\
\text { Male cotton workers } \\
\text { Female cotton workers } \\
\text { Cotton workers }>41 \text { y } \\
\text { Cotton workers } \leqslant 41 \text { y } \\
\text { Symptom free cotton workers } \\
\text { Symptom free office staff } \\
\text { Cotton workers with symptoms but not of byssinosis } \\
\text { Byssinotic cotton workers } \\
\text { Exposed to }>1 \text { mg/m } \mathrm{m}^{3} \text { dust } \\
\text { Exposed to }>5000 \mathrm{CFU} / \mathrm{m}^{3} \text { bacteria } \\
\text { Cardroom workers }\end{array}$ & $\begin{array}{r}162 \\
162 \\
162 \\
161 \\
69 \\
92 \\
133 \\
28 \\
71 \\
62 \\
68 \\
65 \\
55 \\
16 \\
62 \\
16 \\
69 \\
21 \\
23\end{array}$ & $\begin{array}{l}3 \cdot 7(2 \cdot 9,4 \cdot 5) \\
3 \cdot 4(2 \cdot 7,4 \cdot 2) \\
3 \cdot 1(2 \cdot 4,3 \cdot 9) \\
3 \cdot 3(2 \cdot 7,3 \cdot 8) \\
5 \cdot 5(4 \cdot 8,6 \cdot 1) \\
1 \cdot 9(1 \cdot 2,2 \cdot 6) \\
3 \cdot 4(2 \cdot 8,3 \cdot 9) \\
3 \cdot 9(3 \cdot 0,4 \cdot 8) \\
3 \cdot 0(2 \cdot 2,3 \cdot 7) \\
3 \cdot 8(3 \cdot 0,4 \cdot 7) \\
4 \cdot 1(3 \cdot 3,5 \cdot 0) \\
2 \cdot 6(1 \cdot 8,3 \cdot 4) \\
2 \cdot 9(2 \cdot 1,3 \cdot 8) \\
3 \cdot 7(2 \cdot 4,5 \cdot 0) \\
3 \cdot 9(3 \cdot 1,4 \cdot 8) \\
2 \cdot 7(0 \cdot 8,4 \cdot 7) \\
3 \cdot 3(2 \cdot 4,4 \cdot 1) \\
2 \cdot 9(1 \cdot 5,4 \cdot 4) \\
2 \cdot 4(1 \cdot 1,3 \cdot 8)\end{array}$ & $\begin{array}{l}13 \cdot 19(12 \cdot 41,13 \cdot 54) \\
13 \cdot 14(13 \cdot 35,13 \cdot 49) \\
13 \cdot 15(12 \cdot 34,13 \cdot 52) \\
13 \cdot 05(12 \cdot 36,13 \cdot 31) \\
13 \cdot 26(13 \cdot 05,13 \cdot 47) \\
12 \cdot 52(11 \cdot 39,14 \cdot 02) \\
12 \cdot 57(12 \cdot 27,13 \cdot 27) \\
14 \cdot 44(14 \cdot 05,15 \cdot 20) \\
12 \cdot 58(12 \cdot 13,13 \cdot 40) \\
12 \cdot 57(12 \cdot 10,13 \cdot 35) \\
12 \cdot 44(12 \cdot 05,13 \cdot 19) \\
13 \cdot 18(12 \cdot 23,14 \cdot 08) \\
13 \cdot 35(12 \cdot 49,14 \cdot 20) \\
14 \cdot 45(13 \cdot 48,15 \cdot 36) \\
12 \cdot 39(11 \cdot 56,13 \cdot 57) \\
12 \cdot 15(8 \cdot 37,14 \cdot 24) \\
12 \cdot 55(12 \cdot 08,13 \cdot 37) \\
13 \cdot 22(11 \cdot 43,14 \cdot 38) \\
12 \cdot 52(11 \cdot 01,14 \cdot 27)\end{array}$ \\
\hline
\end{tabular}


Table 4 Mann-Whitney test for difference in amplitude of the PEFR rhythm between younger and older cotton workers and between those with and without symptoms

\begin{tabular}{lllll}
\hline Group (cotton workers only) & No of workers & $\begin{array}{l}\text { Median amplitude } \\
\text { (\% of day means) }\end{array}$ & U value & $p$ value \\
\hline Age $\leqslant 41$ y & 65 & $3 \cdot 43$ & 1660 & $0 \cdot 013$ \\
Age $>41$ y & 68 & $4 \cdot 32$ & 1689 & $0 \cdot 037$ \\
With symptoms & 62 & $4 \cdot 32$ & $3 \cdot 40$ & \\
Symptom free & 55 & & \\
\hline
\end{tabular}

ing to the Mann-Whitney non-parametric test (table 4) the mean amplitude in cotton workers claiming to suffer from bronchitic symptoms was significantly higher than their symptom free counterparts $(\mathrm{p}<$ $0 \cdot 04)$, as was the amplitude in older cotton workers compared with that of their younger colleagues $(\mathrm{p}<$ $0 \cdot 02$ ). The mean amplitude in female cotton workers was higher than in men but this difference was not significant. These observations agree closely with earlier reports.

\section{Discussion}

We had no reason to doubt that the participants performed and recorded their PEFR in their home effectively. Having carefully trained the participants (who were all willing volunteers) in using the mini peak flow meter, we frequently saw them during working hours on the study days and encouraged them to "blow" to the best of their ability. The three who did not were excluded from the study. In the great majority of cases, all values in the triplicate readings were within $10 \%$ of the maximum value. The participants wore their dust samplers during work shifts without indicating any discomfort. Many participants were badly educated; a few had difficulties with the English language. Nevertheless, we consider the data collected to be sufficiently reliable for the present purpose.

In analysing the PEFR rhythm we chose to use the highest value of the two hourly triplicate readings because this fitted in well with the nature of PEFR measurement (using mean values, however, yielded similar results). We normalised each PEFR reading from an individual at a given time of day to a percentage of his or her average reading for the daywhich did not, of course, include readings during sleep: the "sleep" portion of the rhythm was merely extrapolated from waking measurements. Consequently, our calculated PEFR level for a given day falls somewhat above the true mesor for that day. This would not, however, have influenced either the amplitude, which is the difference between the peak and trough of the rhythm, or the acrophase. Furthermore, the way individual rhythms were combined to yield the mean rhythm in a group influenced the mean acrophase. Individuals with large amplitudes contributed relatively more to the mean acrophase than those with small ones.

In general, groups of workers exposed to high concentrations of airborne cotton dust, such as card- . room and winding room workers, those suffering $\overrightarrow{0}$ from byssinosis, and those exposed to over $5000 \mathrm{CFU} / \mathrm{m}^{3}$ bacteria or over $1 \mathrm{mg} / \mathrm{m}^{3}$ airborne dust (table 3 ), tended to display a circadian rhythm in PEFR with amplitudes somewhat less than those in less exposed groups such as office staff. The multiple linear regression analysis has shown that, in addition to the presence or absence of bronchitic $\stackrel{\Phi}{-}$ symptoms and age, whether or not a person works in $\overrightarrow{0}$ a cardroom makes some contribution to the variability in amplitude. Interestingly, factors such as the presence or absence of byssinotic symptoms or actual dust exposure levels did not appear to be relevant. Nevertheless, the trend in the PEFR rhythm (decrease in amplitude) corresponded to that in FEV ${ }_{1}$ and FVC, which fell slightly during the 2 work shift in dustry workrooms, especially in a card- $\overrightarrow{\bar{O}}$ room (table 2), instead of rising as they should $\exists$ have done according to their normal circadian rhythm. ${ }^{21}$ Thus, as might have been expected, exposure to cotton dust probably reduced the morning rise in PEFR, possibly for the same reasons as it lowered the $\mathrm{FEV}_{1}$ or FVC - that is, by inducing bronchial constriction. If the morning rise was reduced then so was the night fall in PEFR, which was merely extrapolated from the morning risehence the decrease in amplitude. We believe that exposure to cotton dust probably accounted for the 음 difference between the PEFR amplitudes we $(5.5 \%)$ 응 and Hetzel and Clark $(8 \cdot 3 \%)^{1}$ observed in groups of participants with individually significant rhythms. N

The mean amplitude of PEFR rhythm in the group of 16 workers with byssinosis $(2 \cdot 7 \%)$ was quite unlike the amplitude observed in the seven- $\mathbb{N}$ teenth byssinotic worker $(25 \%)$, who was excluded from the study, or the amplitudes reported ine patients with asthma in the past. Thus byssinosis in 16 out of 17 cases did not resemble asthma, at least ${ }^{+}$ so far as the PEFR rhythm was concerned. The seventeenth worker could have suffered from both byssinosis and asthma.

We wish to thank the Cotton Industry War Memor-? 
ial Trust for financial support, the management and the Amalgamated Textile Workers' Union for their help, the participants for giving so much of their time and effort, Mr Michael Tereshchuk for technical assistance, and Dr DS Minors for advice.

\section{References}

${ }^{1}$ Hetzel MR, Clark TJH. Comparison of normal and asthmatic circadian rhythm in peak expiratory flow rate. Thorax 1980;35:732-8.

${ }^{2}$ Reindl K, Falliers C, Chai H, Hillman D, Nelson W. Circadian acrophase in peak expiratory flow rate and urinary electrolyte excretion of asthmatic children: phase shifting of rhythms by prednisone given in different circadian system phases. Rass Neural Veg 1970;23:5-26.

${ }^{3}$ Reinberg A, Gervais P. Circadian rhythms in respiratory function with special reference to human chronophysiology and chronopharmacology. Bull Physiopathol Respir 1970;8:663-72.

4 Gaultier R, Reinberg A, Girard F. Circadian rhythm in lung resistance and dynamic lung compliance of healthy children. Respir Physiol 1977;31:169-82.

${ }^{5}$ Dawkins KD, Muers MF. Diurnal variation in airflow obstruction in chronic bronchitis. Thorax 1981;36:618-21.

6 McKerrow CB, McDermott M, Gilson JC, Schilling RSF. Respiratory function during the day in cotton workers: a study in byssinosis. $\mathrm{Br} J$ Ind Med 1958; 15: 75-83.

${ }^{7}$ Gilson JC, Stott H, Hopwood BEC, Roach SA, McKerrow CB, Schilling RSF. Byssinosis: the acute effect of ventilation capacity of dusts in cotton ginneries and cotton, sisal and jute mills. Br J Ind Med 1962;19:9 19.

${ }^{8}$ El Batawi MA, Schilling RSF, Valic F, Walford J. Byssinosis in Egyptian cotton industry: changes in ventilatory capacity during the day. $\mathrm{Br} J$ Ind Med 1964;21:13-9.

${ }^{9}$ Mair A, Smith DH, Wilson WA, Lockhart W. Dust disease in Dundee textile workers: an investigation into chronic respiratory disease in jute and flax industries. Br J Ind Med 1960;17:272-8.

${ }^{10}$ Bouhuys A, van Duyn J, van Lennep J. Byssinosis in flax workers. Arch Environ Health 1961;3:499-509.
"Bouhuys A, Barbero A, Lindell SE, Roach SA, Schilling RSF. Byssinosis in hemp workers. Arch Environ Health $1967 ; 14: 533-44$.

12 Valic F, Zuskin E, Walford J, Kersic W, Paukovic R. Byssinosis, chronic bronchitis and ventilatory capacities in workers exposed to soft hemp dust. $\mathrm{Br} J$ Ind Med 1968;25:176-86.

${ }^{13}$ Gandevia B, Milne J. Ventilatory capacity on exposure to jute dust and relevance of productive cough and smoking to the response. $\mathrm{Br} J$ Ind Med 1965;22:187-95.

${ }^{14}$ Zuskin E, Valic F, Bouhuys A. Effect of wool dust on respiratory function. Am Rev Respir Dis 1976; 114:705-9.

${ }^{15}$ Valic F, Beretic D, Butkovic D. Respiratory response to tobacco dust exposure. Am Rev Respir Dis 1976; 113:751-5.

${ }^{16} \mathrm{Al}$ Zuhair YS, Whitaker CJ, Cinkotai FF. Ventilatory function in workers exposed to tea and wood dust. $\mathrm{Br}$ $J$ Ind Med 1981;38:339-45.

${ }^{17}$ Lapp NL, Hankinson JL, Burgess DB, O'Brien R. Changes in ventilatory function in coal miners after a workshift. Arch Environ Health 1972;24:204-8.

${ }^{18}$ Love RG. Lung function studies before and after a workshift. Br J Ind Med 1983;40:153-9.

19 Walford Joan, Lammers B, Schilling RSF, van den Hoven van Genderen D, van der Veen YG. Diurnal variation in ventilatory capacity. $\mathrm{Br} \mathrm{J}$ Ind Med 1966;23:142.

${ }^{20}$ Lewinsohn HC, Capel LH, Smart J. Changes in forced expiratory volumes throughout the day. $\mathrm{Br}$ Med J $1960 ; 1: 462-4$.

${ }^{21}$ Guberan E, Williams MK, Walford J, Smith MM. Circadian variation of FEV in shift workers. $B r J$ Ind Med 1969; 26: 121-5.

${ }^{24}$ Nelson W, Liang Tong Y, Tung-Kuen Lee, Halberg F. Methods for cosinor-rhythmometry. Chronobiologia 1979;6:305-23.

${ }^{23}$ Bingham C, Arbogast B, Guillaume GC, Tung-Kuen Lee, Halberg F. Inferential statistical methods for estimating and comparing cosinor parameters. Chronobiologia 1982;9:397-439.

${ }^{24}$ System 1360 scientific subroutine package, Version III, IBM program manual. Program No. 360A-CM-03X. 5th ed. GH20-0205-4, app 13, 408-12.

${ }^{25}$ Hull CH, Nie NH. Statistical package for the social sciences. New York: McGraw-Hill, 1981. 